\title{
Influence of Vermicompost with Microbial Consortia on Number and Weight of Chrysanthemum Flower (Dendranthema grandiflora L.) cv. Marigold
}

\author{
Sharukh Khan', M. Venkatesha ${ }^{2}$ and D. Raghupathi ${ }^{3 *}$ \\ ${ }^{1}$ Department of Horticulture, College of Agriculture University of Agricultural Sciences \\ Bengaluru- 560065, India \\ ${ }^{2}$ Department of Horticulture, College of Agriculture, V.C.Farm, Mandya- 571405, India \\ ${ }^{3}$ Directorate of Extension, University of Agricultural Sciences, Zonal Agricultural Research \\ Station, V.C.Farm, Mandya-571405, India \\ *Corresponding author
}

\section{A B S T R A C T}

\section{Keywords}

Microbial consortia, Vermicompost,

Recommended dose of fertilizer,

Number of flowers,

Weight of the

flowers.

Article Info

Accepted:

04 March 2020

Available Online:

10 April 2020
The chemical fertilisers when applied to soil more than the recommended, it not only affects the yield of flowers but also affects on deterioration of soil health. As an alternative to this, the low cost bio-fertilisers are one of the solutions which will help the farmers to reduce the cost of cultivation. This need to experimented. In view of this, the study was conducted to find out the influence of Vermicompost in combination with Microbial Consortium on reproductive parameters of Chrysanthemum (Dendranthema grandiflora L.) cv. Marigold. The work was carried out during Kharif 2018-19 consist of 10 Treatments and 3 Replications. The findings of the study revealed that Chrysanthemum supplied with Vermicompost +50 per cent $\mathrm{RDF}+\mathrm{AMC}$ i.e., treatment 9 recorded significantly higher in numbers and weight of flowers, which proportionately increased the flower yield when compared to the remaining treatments observed.

\section{Introduction}

Chrysanthemum (Dendranthema grandiflora L.) is an herbaceous perennial flowering plant extensively grown all over the world. It belongs to the family Asteraceae. It is an ornamental flower crop and valued as a potted plant and is the commercially cultivated cut flower crop in many countries and widely grown in open fields in India for their loose flowers. There is a need for evaluation of Chrysanthemum cultivars with respect to highest number and the best quality flowers under integrated soil fertility management practices involving reasonable combination of organic mixtures, biofertilizers and chemical fertilizers seem to be attainable. Therefore, the present study is focused on the use of organic manures such as Vermicompost, Biofertilizers, Farm yard manure and Arka 
microbial consortia and Microbial consortia from IIHR and UASB, respectively for Chrysanthemum.

\section{Materials and Methods}

The experiment was conducted in the Department of Horticulture, Precision Farming Development Centre, Gandhi Krishi Vigyana Kendra, University of Agricultural Sciences, Bengaluru, Karnataka State, by using cv. Marigold.

The Treatment details are: $100 \%$ RDF Control $\left(\mathrm{T}_{1}\right), \quad 100 \% \quad \mathrm{FYM} \quad\left(\mathrm{T}_{2}\right), \quad 100 \%$ Vermicompost $\left(\mathrm{T}_{3}\right), 100 \% \mathrm{RDF}+\mathrm{FYM}(\mathrm{POP})$ $\left(\mathrm{T}_{4}\right)$, Vermicompost $+75 \%$ RDF $\left(\mathrm{T}_{5}\right)$, Vermicompost $+75 \%$ RDF + AMC $\left(\mathrm{T}_{6}\right)$, Vermicompost $+75 \% \quad \mathrm{RDF}+\mathrm{MC} \quad\left(\mathrm{T}_{7}\right)$, Vermicompost $\quad+50 \%$ RDF $\left(\mathrm{T}_{8}\right)$, Vermicompost $+50 \%$ RDF + AMC $\left(\mathrm{T}_{9}\right)$, Vermicompost $+50 \% \mathrm{RDF}+\mathrm{MC}\left(\mathrm{T}_{10}\right)$. Well decomposed organic sources of nutrient like FYM @ 25 tons and Vermicompost @ 7.5 tons per hectare were applied at the time of treatment imposition and mixed with soil.

The recommended dose of 100:150:100 kg NPK/ha were applied in the form of Urea, Single Super Phosphate and Muriate of Potash, respectively. Out of $100 \mathrm{~kg}$ Nitrogen, 50 per cent Nitrogen and full dose of $\mathrm{P}_{2} \mathrm{O}_{5}$ and $\mathrm{K}_{2} \mathrm{O}$ were applied in a circular band about 10 $\mathrm{cm}$ around each plant and remaining 50 per cent Nitrogen was applied 30 days after planting. Bio-fertilizer like MC and AMC are applied to base of the plant (@ 5g/plant) as drenching.

Yield data was recorded by counting the number of flowers at the time of each harvest and average number of flowers produced per plant was calculated. Total number of flowers produced per plot was computed by multiplying the average number of flowers produced by a plant in its life period per unit area. Total number of flowers produced per hectare was calculated by multiplying the average number of flowers obtained per plant into number of plants in one hectare (Fig. 1).

\section{Results and Discussion}

The results indicated that the flower weight and number of flowers are significantly increased and differed due to application of organic manures, biofertilizers and inorganic fertilizers, at all the stages of crop growth. Chrysanthemum plants treated with Vermicompost +50 per cent $\mathrm{RDF}+\mathrm{AMC}$ $\left(\mathrm{T}_{9}\right)$ registered highest 12.72 lakh number of flowers per hectare which was significantly higher than other treatments. The lowest number of flowers i e., 9.3 lakh per hectare was recorded for plants supplied with 100 per cent RDF alone $\left(\mathrm{T}_{1}\right)$.

Significantly highest number of flowers produced per plant, plot and hectare was recorded in treatment received organic, inorganic and biofertilizers combinations (Table 1 and Fig. 2). The possible reason is that the microbial consortium helps to uptake of nutrients, which in turn leads to more number of leaves and branches.

More photosynthesis enhanced food accumulation which might have resulted in better plant growth and subsequently higher number of flowers per plant and hence more number of flower yield per hectare. Beside this, increase in flower yield may be attributed to increased availability of phosphorous and its greater uptake because of Arka microbial consortia contain the phosphorus solubilising bacteria which help to solubilise the phosphorus in soil and easily made available to plant and application of inorganic fertilizer help to increase the yield by the increasing the number of branches and number leaves that will lead to increase in the yield. 
Vermicompost being the source of macro and micro nutrients like Iron and Zinc enzymes, growth hormones and beneficial effects of micro flora might have played a secondary role in increasing the flower number and weight. Number of flowers per plant might have increased with the increase in number of branches per plant as well as due to the effect of inoculants capable of providing phosphorous useful in increasing the number of flowers per plant (Laishram et al., 2013).

Availability of ample quantity of macro and micro nutrients in vermicompost might have also added to the production of more number of flowers per plant, besides this, vermicompost enhances photosynthesis efficacy which may have enhanced food accumulation resulting in better plant growth and subsequently higher number of flowers per plant (Sunitha and Hunje, 2010).
The flower weight per plant, plot and hectare are also influenced by use of vermicompost and microbial consortia in chrysanthemum cv. Marigold. The data on parameter of the chrysanthemum as influenced by integrated nutrient management indicates that application of Vermicompost +50 per cent $\mathrm{RDF}+\mathrm{AMC}\left(\mathrm{T}_{9}\right)$ gave significantly maximum flower weight per plant $(232.62 \mathrm{~g})$. However, minimum flower weight per plant $(174.13 \mathrm{~g})$ was recorded in the treatment $\left(\mathrm{T}_{1}\right)$ control (Table 2 and Fig. 3).

Application of Vermicompost +50 per cent $\mathrm{RDF}+\mathrm{AMC}\left(\mathrm{T}_{9}\right)$ has recorded significantly maximum flower yield of $7.68 \mathrm{~kg}$ per plot followed by treatment supplied with Vermicompost + 75\% RDF + AMC $\left(\mathrm{T}_{6}\right) 7.40$ $\mathrm{kg}$ per plot respectively. However, minimum flower yield of $5.75 \mathrm{~kg}$ per plot was recorded in control plot $\left(\mathrm{T}_{1}\right)$.

Table.1 Effect of vermicompost and microbial consortia on number of flowers in Chrysanthemum cv. Marigold

\begin{tabular}{|l|c|c|c|}
\hline \multicolumn{1}{|c|}{ Treatments } & $\begin{array}{c}\text { Number of } \\
\text { flowers /plant }\end{array}$ & $\begin{array}{c}\text { Number of } \\
\text { flowers /plot }\end{array}$ & $\begin{array}{c}\text { Number of } \\
\text { flowers } / \text { ha }\end{array}$ \\
\hline $\mathbf{T}_{\mathbf{1}}-\mathbf{1 0 0 \%}$ RDF (control) & 19.80 & 625.36 & $\mathbf{9 3 5 3 3 9 . 5 8}$ \\
\hline $\mathbf{T}_{\mathbf{2}}-\mathbf{1 0 0 \%}$ FYM & 20.67 & 683.79 & $\mathbf{1 0 2 2 7 3 2 . 2 7}$ \\
\hline $\mathbf{T}_{\mathbf{3}}-\mathbf{1 0 0 \%}$ Vermicompost & 21.07 & 705.62 & $\mathbf{1 0 5 5 3 8 3 . 0 0}$ \\
\hline $\mathbf{T}_{\mathbf{4}}-\mathbf{1 0 0 \%}$ RDF+ FYM(POP) & 22.53 & 754.85 & $\mathbf{1 1 2 9 0 1 5 . 4 2}$ \\
\hline $\mathbf{T}_{\mathbf{5}}-$ Vermicompost +75\% RDF & 21.87 & 721.60 & $\mathbf{1 0 7 9 2 8 4 . 0 0}$ \\
\hline $\mathbf{T}_{\mathbf{6}}$-Vermicompost +75\% RDF+ AMC & 23.20 & 793.21 & $\mathbf{1 1 8 6 3 8 9 . 7 8}$ \\
\hline $\mathbf{T}_{\mathbf{7}}-$ Vermicompost+75\% RDF+ MC & 23.07 & 726.59 & $\mathbf{1 0 8 6 7 4 7 . 4 5}$ \\
\hline $\mathbf{T}_{\mathbf{8}}$ - Vermicompost +50\% RDF & 21.47 & 708.40 & $\mathbf{1 0 5 9 5 4 1 . 0 0}$ \\
\hline $\mathbf{T}_{\mathbf{9}}-$ Vermicompost+50\% RDF + AMC & 25.13 & 850.62 & $\mathbf{1 2 7 2 2 5 6 . 8 7}$ \\
\hline $\mathbf{T}_{\mathbf{1 0}}$-Vermicompost +50\% RDF + MC & 22.73 & 776.63 & $\mathbf{1 1 6 1 5 9 1 . 3 7}$ \\
\hline F-test & $*$ & $*$ & $*$ \\
\hline S.Em \pm & 0.95 & 35.53 & $\mathbf{5 3 1 4 7 . 6 6}$ \\
\hline C.D.at 5\% & 2.82 & 105.58 & $\mathbf{1 5 7 9 0 9 . 8 0}$ \\
\hline
\end{tabular}

*Significant at $5 \%$ confidence level

Note: AMC- Arka Microbial Consortium (IIHR); DAT - Days after Transplanting;

FYM - Farm Yard Manure (25 t/ha.); MC - Microbial Consortium (UASB); POP- Package of practice; RDFRecommended Dose of Fertilizer (100:150:100 kg /ha N: P: K); VC- Vermicompost-7.5 t/ha 
Table.2 Effect of vermicompost and microbial consortia on flower weight of chrysanthemum cv. Marigold

\begin{tabular}{|c|c|c|c|}
\hline Treatments & $\begin{array}{l}\text { weight of } \\
\text { flowers / } \\
\text { plant (g) }\end{array}$ & $\begin{array}{l}\text { weight of } \\
\text { flowers / } \\
\text { plot (kg) }\end{array}$ & $\begin{array}{l}\text { weight of } \\
\text { flowers / } \\
\text { hectare (t) }\end{array}$ \\
\hline$T_{1}-100 \%$ RDF (control) & 174.13 & 5.75 & 8.56 \\
\hline$T_{2}-100 \%$ FYM & 197.03 & 6.50 & 9.69 \\
\hline$T_{3}-100 \%$ Vermicompost & 198.79 & 6.56 & 9.77 \\
\hline$T_{4}-100 \%$ RDF+ FYM(POP) & 204.52 & 6.75 & $\mathbf{1 0 . 0 5}$ \\
\hline $\mathrm{T}_{5}-$ Vermicompost $+75 \%$ RDF & 204.89 & 6.76 & 10.07 \\
\hline $\mathrm{T}_{6}$-Vermicompost $+75 \% \mathrm{RDF}+\mathrm{AMC}$ & 224.46 & 7.41 & 11.03 \\
\hline $\mathrm{T}_{7}$-Vermicompost+75\% RDF+ MC & 213.77 & 7.05 & 10.51 \\
\hline $\mathrm{T}_{8}$-Vermicompost $+\mathbf{5 0} \%$ RDF & 217.96 & 7.19 & 10.71 \\
\hline 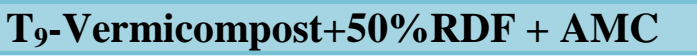 & 232.62 & 7.68 & 11.44 \\
\hline $\mathrm{T}_{10}-$ Vermicompost $+50 \%$ RDF + MC & 212.28 & 7.01 & 10.44 \\
\hline F-test & $*$ & $*$ & $*$ \\
\hline S.Em \pm & 10.26 & 0.33 & 0.49 \\
\hline C.D.at $5 \%$ & 30.49 & 0.99 & 1.47 \\
\hline
\end{tabular}

*Significant at 5\% confidence level

Note: AMC- Arka Microbial Consortium (IIHR); DAT- Days after Transplanting;

FYM - Farm Yard Manure (25 t/ha.); MC - Microbial Consortium (UASB); POP- Package of Practice; RDFRecommended Dose of Fertilizer (100:150:100 kg /ha N: P: K); VC- Vermicompost-7.5 t/ha

Fig.1 Chrysanthemum at flowering stage

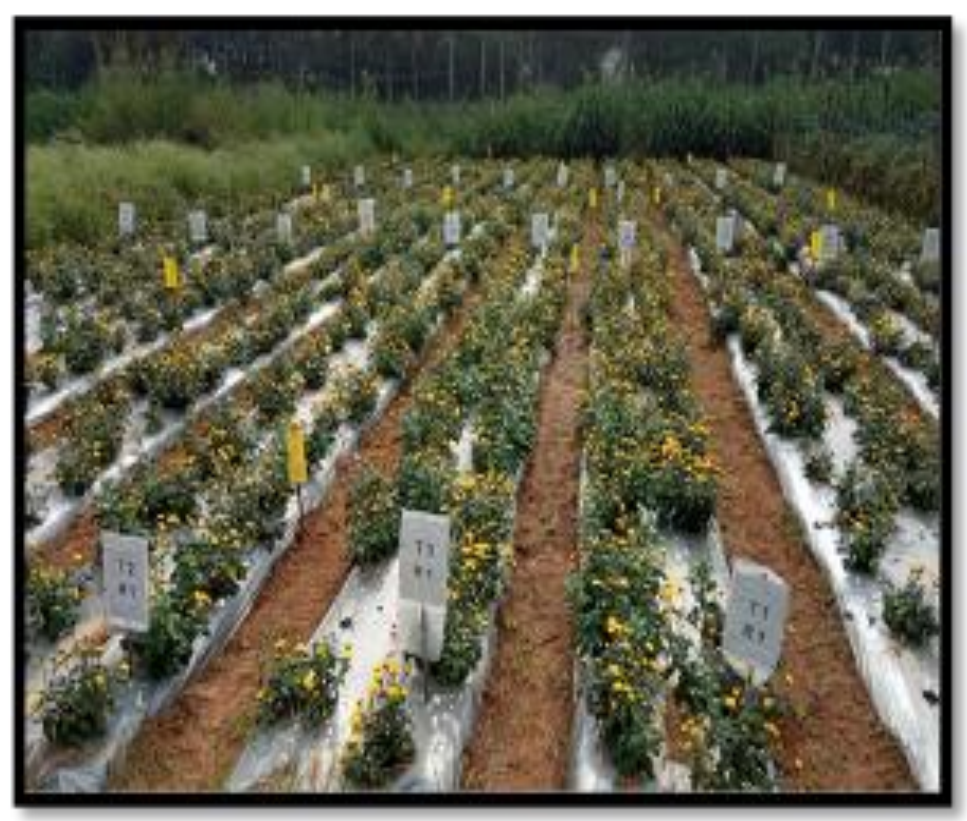


Fig.2 Influence of vermicompost and microbial consortium on number of flowers per plant in chrysanthemum cv. Marigold

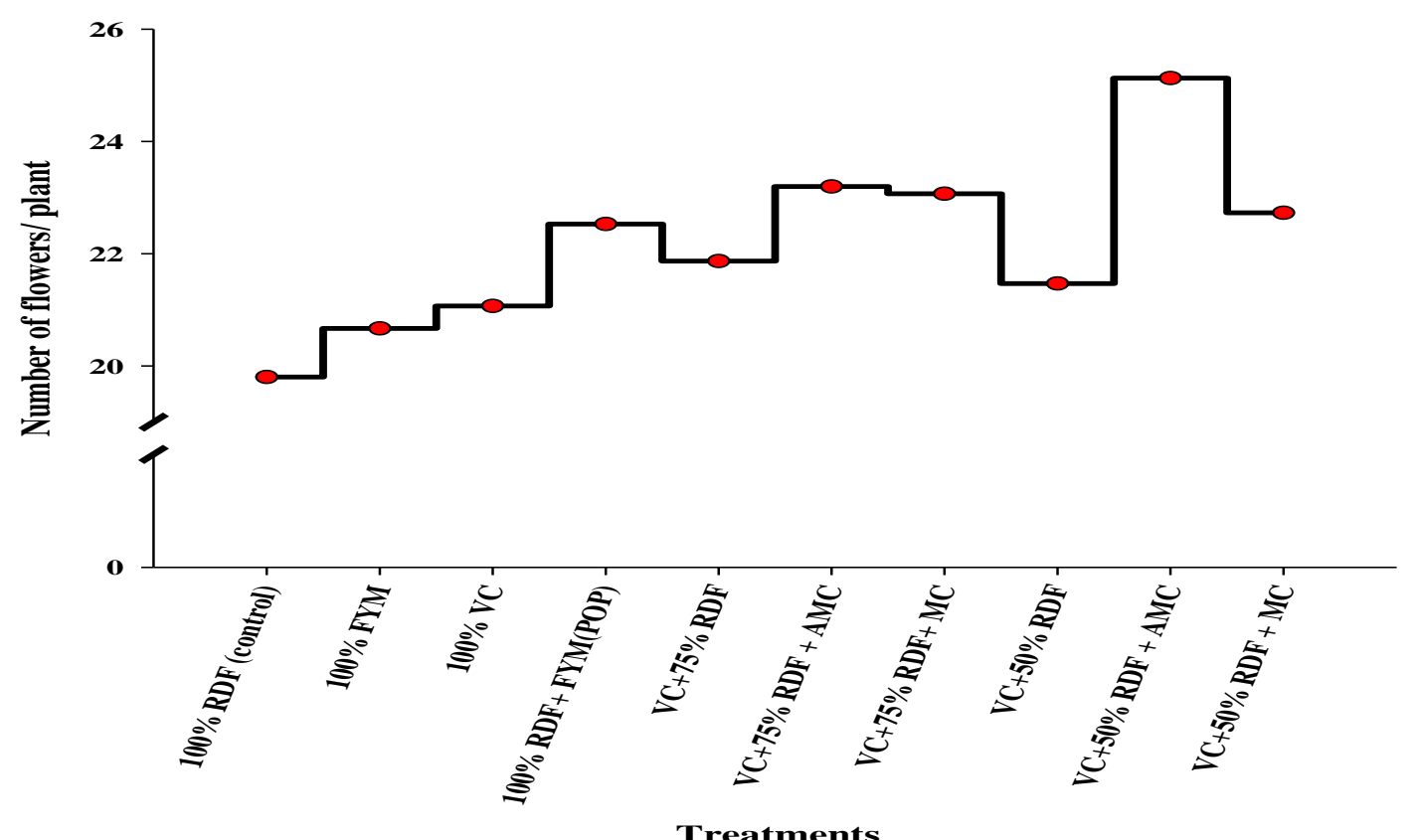

Fig.3 Influence of vermicompost and microbial consortia on yield of chrysanthemum cv. Marigold

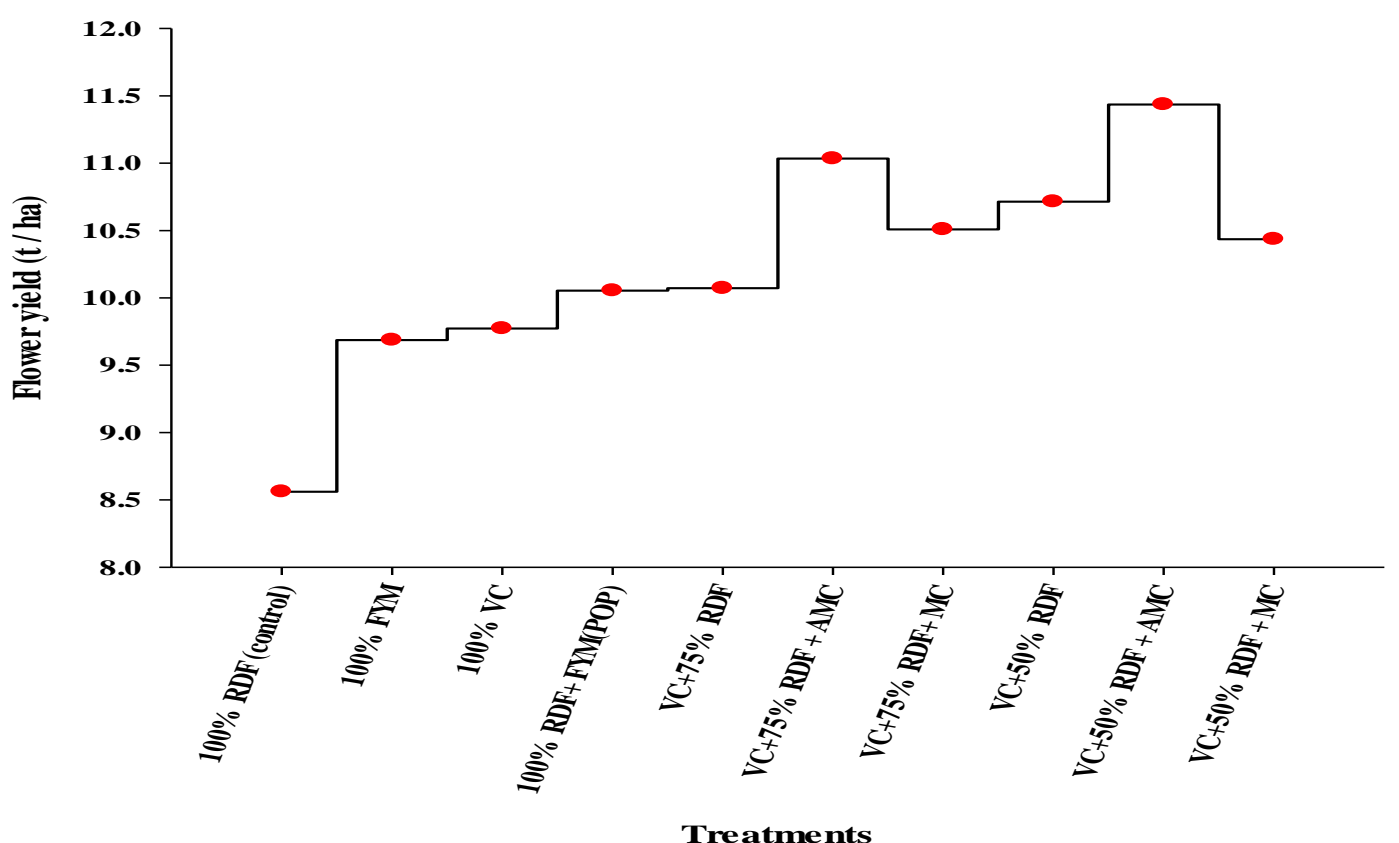


Flowers yield per hectare was significantly affected by different source of nutrient and bio fertilizers application in chrysanthemum. The flower yield recorded per hectare is ranged from 8.56 to 11.43 tonnes for treatment supplied with 100 per cent RDF and Vermicompost +50 per cent $\mathrm{RDF}+\mathrm{AMC}$ $\left(\mathrm{T}_{9}\right)$ plot respectively.

Vermicompost being the source of macro and micro nutrients like iron and zinc enzymes, growth hormones and beneficial effects of micro flora might have played a pivotal role in increasing the flower yield. The increase in number of flowers may be due to possible role of better root proliferation, uptake of nutrients and water. More photosynthesis enhanced food accumulation which might have resulted in higher number of flowers per plant and hence, more number of flower yield per hectare. Besides, increase in flower yield might be attributed to increased availability of phosphorus and its greater uptake (Gaur, 1980).

The increase in number of branches may be attributed to vermicompost application which might have supplied plant nutrients directly to the plant resulting in stimulation of auxiliary buds thereby increasing number of branches per plant and also application of vermicompost which is considered as an excellent product as it is homogenous and has desirable properties, reduced level of contaminates, higher level of soil enzymes, plant growth hormones, greater microbial population and holds more nutrients over a longer period without adversely affecting the environment. The above results are in corroborate with the findings of Nethra et al., (1999) in China aster and Kusuma (2001) in Golden Rod.

To conclude, the results revealed that application of different sources of nutrients significantly enhanced the reproductive parameters in chrysanthemum cv. Marigold. It can be concluded that, application of vermicompost in combination with 50 per cent NPK and microbial consortium amalgamation/integration helps to maintain the soil fertility status to get sustainable crop yield and it is eco friendly in place of using inorganic fertilizers which are costly and causing long term effects on flora, fauna and eco-system, should be discouraged slowly. Application of Vermicompost $+50 \% \mathrm{RDF}+$ AMC (T9) has significantly increased number of flowers and weight of flowers compared to other treatments combination selected for the study. The other adaphic and climatic factors are might have also influenced indirectly for the overall yield of the chrysanthemum flowers.

\section{Acknowledgement}

I acknowledge the support given by esteemed University for the opportunity to guide the M.Sc student. I also thank the advisory committee members in guiding the students and completion of his M.Sc program successfully. Finally I express gratitude to the Teachers and Friends for supporting and completing the research works.

\section{References}

Gaur, A.C., 1980, Response of rice to organic matter: The Indian experience, organic matter and rice. International rice research institute, Los Banos, Philippines: 503-514.

Kumar, P., Raghava, S. P. S., and Mishra, R. L., 2003, Effect of biofertilizers on growth and yield of China aster. Journal of Ornamental Horticulture, 6 (2): 85-88.

Kusuma, G., 2001, effect of organic and inorganic fertilizers on growth yield and quality of Golden rod (Solidago candensis L) M.Sc. (Hort) Thesis 
College of Agriculture, University of Agricultural Sciences, Dharwad, Karnataka.

Laishram, N., Dhiman, S.R., Gupta, Y. C., Bhardwaj, S. K and Singh, A., 2013, Microbial dynamics and physicochemical properties of soil in the rhizosphere of chrysanthemum (Dendranthema grandiflora) as influenced by integrated nutrient management. Indian Journal of Agricultural Sciences, 83(4): 447-455.

Mashaldi, A., 2000, Effect of organic and inorganic fertilizers on growth, yield and post-harvest life of marigold (Tagetes erecta L.) cv. Double orange. M. Sc. (Agri.) thesis, University of Agricultural Sciences, Dharwad, Karnataka.
Nethra, N. N., Jayaprasad, K. V. and Radha, D. K., 1999, China aster (Callistephus chinensis L.) cultivation using vermicompost as organic amendment. Crop Research, 17(2): 209-215.

Sunitha, H. M. and Hunje, 2010, Effect of plant spacing and integrated nutrient management on yield and quality of seed and vegetative growth parameters in African marigold (Tagetes erecta L.). Journal of Ornamental Horticulture, 10(4): 245-249.

Syamal, M. M., Dixit, S. K. and Kumar. S., 2006, Effect of bioinoculants on growth and yield in marigold. Journal of Ornamental Horticulture, 9: 304305.

\section{How to cite this article:}

Sharukh khan, M. Venkatesha and Raghupathi, D. 2020. Influence of Vermicompost with Microbial Consortia on Number and Weight of Chrysanthemum Flower (Dendranthema grandiflora L.) cv. Marigold. Int.J.Curr.Microbiol.App.Sci. 9(04): 167-173. doi: https://doi.org/10.20546/ijcmas.2020.904.021 